UDC 621.565.9:620.91

DOI: 10.15587/2706-5448.2021.235594

Article type «Reports on Research Projects»

\author{
Larisa Morozyuk, \\ Viktoriia Sokolovskaya-Efimenko, \\ Yaroslav Petushkov, \\ Maksym Sharaiev, \\ Sergii Psarov
}

\title{
DESIGN OF A REFRIGERATED COMPLEX FOR SHORT-TERM STORAGE OF TROPICAL FRUITS WITH A SOLAR ENERGY PLANT
}

The object of research is a refrigerated complex for short-term storage of tropical fruits in conditions of significant seasonal and daily fluctuations in ambient temperature, that typical for regions with a tropical climate. One of the problems is that the complexes are autonomous small firms for the year-round processing and storage of tropical fruits, located far from the central electric networks. In the presence of solar radiation, the complexes receive energy from small solar power plants. Such complexes are called «trigeneration system». In the course of the study, data on modes were used low temperature heat treatment and preservation of various tropical fruits, ripening times and climatic conditions of Tunisia. It has been established that citrus fruits are stored in chambers with high temperature, olives are frozen and stored for a short time before processing. The total amount of heat entering the citrus chambers is determined by changes in the ambient temperature. The thermal load of the olives chamber is determined by the heat treatment time. It was found that the cargo capacity of chambers with different temperatures differs six times. The thermal load of the olive storage chambers is only four times less. This is due to the peculiarities of the building structure of the complex, technological processes of cooling and freezing. Based on the thermal calculation, the cooling of the chambers is provided by a two-stage booster refrigeration machine with $\mathrm{CO}_{2}$ refrigerant in a transcritical cycle. To ensure the operation of the complex, a solar photoelectric converter is designed. This ensures the environmental safety of the complex and the possibility of obtaining energy savings by regulating the thermal power of the compressors with frequency converters, depending on the ambient temperature. The designed complex can be offered to a private investor for practical implementation.

Keywords: short-term storage of tropical fruits, transcritical two-stage refrigeration machine, solar photovoltaic converter.

Morozyuk, L., Sokolovskaya-Efimenko, V., Petushkov, Y., Sharaiev, M., Psarov, S. (2021). Design of a refrigerated complex for short-term storage of tropical fruits with a solar energy plant. Technology Audit and Production Reserves, 3 (3 (59)), 50-57. doi: http://doi.org/10.15587/2706-5448.2021.235594

\section{Introduction}

In international relations, special importance is attached to the food problem. This problem is an intertwining of the interests of the individual, social groups, society and the world community as a whole to meet the food needs of people. Recently, the manifestations of the food problem are dramatic, as they bear the imprint of the contradictions of modern technological civilization [1,2].

The true scale and urgency of the food problem can be judged on the basis of research by the Food, Agriculture Organization of the United Nations (FAO) [3].

As the food problem has become global in nature and character, its decision is connected with prospects of rational distribution of production resources on all planet.

The involvement of developing countries in the world economy, their specialization in the production of tropical and industrial crops can reduce their food security, its autonomy, making it dependent on their export earnings.
Unsatisfactory food production in developing countries is accompanied by increased production of tropical crops, which adversely affects the prices of the latter and reduces the amount of food for which the proceeds from their sale on foreign markets are used [4]

The production of individual crops is tied to certain geographical areas. This gave rise to the rigid specialization of these areas in the production of certain crops. The aggravation of the food problem is due to a number of socio-economic reasons. These include: the implementation of the process of industrialization, the rapid flow of migration of the rural population to the city; low crop yields in developing countries.

The states of North Africa have geographically favorable locations for the use of solar energy resources. The use of renewable energy sources, primarily solar, enables states to reach a new level of energy [5, 6]. For example, the Tunisian Ministry of Energy and Renewable Energy has launched a program to produce electricity from renewable 
sources, which aims to generate one thousand MW of renewable energy capacity in the period 2017-2021 [7].

Using all the achievements of civilization to provide the population of the Earth with food necessary for normal life would help solve this global problem of today [8].

Based on the above, the creation of refrigerated production facilities for short-term storage of agricultural products at the place of its production is an urgent scientific and technical task.

Thus, the object of research is a refrigerated complex for short-term storage of tropical fruits in conditions of significant seasonal and daily fluctuations in ambient temperature, that typical for regions with a tropical climate. The subject of research is the energy and design characteristics of the elements of the refrigeration system. The aim of research is to development of a refrigerated complex for short-term storage of tropical fruits with a solar power plant.

\section{Methods of research}

Plant products of Tunisia [9]. The winter months are fruitful with citrus fruits: lemons, clementines, dates oranges, pomegranates, figs. The new harvest season begins in Tunisia in the second half of March. From the end of April, gardens with peaches and apricots begin to yield. In May, ripen melons, watermelons, strawberries, peaches, apricots, oranges. To them are added just ripe - cherries, plums. Fruits in Tunisia in summer - apples, pears and grapes. August is one of those months when there is a lot of different fruits in the markets, but nothing new ripens. Therefore, in August, the markets appear fruits that are ripe earlier and have been stored for a short time in refrigerators.

Technology of storage of tropical fruits. Conditions and terms of storage of citrus fruits: from 1 to 4 months tangerines depending on a grade, oranges - from 3 to 6 months, lemons - from 5 to 9 months. Citrus fruits are stored at a humidity of $85-90 \%$ and the temperature specified in [10]. When the temperature in storage is reduced to $0-(-1){ }^{\circ} \mathrm{C}$, the incidence of citrus decreases within 1-2 months, but after this period there is a risk of colds.

Olives are harvested in Tunisia in the spring. Farmers pick olives by hand. Bags filled with olives and olive tree cuttings are sent to a special olive mill, where the fruits are ground with the help of grinding stones.

The quality of olives deteriorates during storage between harvest and processing, which negatively affects the final quality of the oil obtained. Therefore, it is important to find ways to store olives for longer periods that will not have a negative impact on the overall quality of the crop.

Researchers tested the effect of freezing olives at negative temperatures close to zero, and found that the quality of olive oils obtained from them can be compared with the quality of oil obtained from unfrozen fruits of the olive tree. The quality of the first cold-pressed olive oil depends on the composition of the fruit during processing.

The solution to prevent quality degradation is to store small containers in freezers at sub-zero temperatures. Analysis of the results of studies [11] showed that the oil extracted from olives frozen at $-4{ }^{\circ} \mathrm{C}$ for one week and stored for three weeks before processing at a moderate temperature, has the characteristics of extracted from fresh olives. Freezing did not reduce the content of useful nutrients. Moreover, there were no differences between the varieties.
Refrigeration systems [12]. In recent years, the importance of $\mathrm{CO}_{2}$ as a refrigerant has grown significantly. Most importantly, $\mathrm{CO}_{2}$ is one of the few refrigerants for refrigeration systems that is promising in terms of environmental safety. $\mathrm{CO}_{2}$ can be used as a refrigerant in refrigeration systems of various types, with a wide range of ambient temperatures.

Transcritical $\mathrm{CO}_{2}$ refrigeration systems are currently used in small and commercial refrigeration machines. Commercial enterprises use all types of $\mathrm{CO}_{2}$ machines: single-stage, twostage and cascade. The choice is determined by the size of the enterprise, the range of products stored and sold.

Energy supply. The use of one or another type of energy resources depends entirely on the location of the consumer near the central power supply networks or away from them. Local energy systems solve the problems of residents of remote settlements, private small manufacturing firms and agricultural industries.

Information on the characteristics of solar radiation during the year [7] indicates a real opportunity to use renewable energy sources, solar energy for year-round operation of the refrigeration system of a production plant of low heat capacity.

Based on the analysis, we design refrigeration chambers for heat treatment and subsequent short-term storage of tropical fruits and olives, taking into account that the harvest is sufficient for full-scale implementation of the project. Energy supply of production is carried out from the solar photovoltaic converter. The project is designed for an individual producer of agricultural products in the climatic conditions of Tunisia.

Research methods: thermodynamic analysis and numerical modeling of thermodynamic processes in the elements of the cooling system. The basis of mathematical modeling is the equations of classical thermodynamics and heat transfer.

\section{Research results and discussion}

3.1. Cargo capacity of chamber. The geometric dimensions of the cameras are due to the existing structures of the premises, which the consumer offers for conversion. Construction and cargo data of storage chambers are given in Table 1 [13].

Table 1

Construction and cargo data of storage chambers

\begin{tabular}{|l|c|c|c|c|c|}
\hline \multicolumn{1}{|c|}{ Indicator } & Marks & $\begin{array}{c}\text { One } \\
\text { dimension }\end{array}$ & $\begin{array}{c}\text { Cham- } \\
\text { ber 1 }\end{array}$ & $\begin{array}{c}\text { Cham- } \\
\text { ber 2 }\end{array}$ & $\begin{array}{c}\text { Cham- } \\
\text { ber 3 }\end{array}$ \\
\hline Temperature & $t_{\text {cham }}$ & ㄷ & 8.0 & 7.0 & -4.0 \\
\hline Relative humidity & $\varphi$ & $\%$ & 85 & 85 & 85 \\
\hline Dimensions: & & & & & \\
length & - & $\mathrm{m}$ & 14.4 & 14.4 & 8.4 \\
width & - & $\mathrm{m}$ & 12,9 & 6.7 & 5.2 \\
height & - & $\mathrm{m}$ & 4.0 & 4.0 & 4.0 \\
square & - & $\mathrm{m}^{2}$ & 186.0 & 96.4 & 43.7 \\
freight area & - & $\mathrm{m}^{2}$ & 140.0 & 72.3 & 30.5 \\
\hline Cargo capacity & - & $\mathrm{kg}$ & 45000 & 12000 & 6000 \\
\hline
\end{tabular}

In chamber 1 (Table 1) lemons are stored in boxes that are installed on 30 racks, weight of a box $-10 \mathrm{~kg}$, on a rack - 150 boxes, height of a stack $-3 \mathrm{~m}$. In chamber 2 apples and tangerines are stored in boxes, which are installed on 9 racks, the weight of the box is $10 \mathrm{~kg}$, on the rack - 150 boxes. In chamber 3 olives are stored 
in boxes which are installed on 4 racks, weight of a box $10 \mathrm{~kg}$, on a rack - 150 boxes.

The total area of the chambers, which are cooled:

$$
F_{\text {cild }}=\left(F_{1}+F_{2}+F_{3}\right)_{b u l d}=326 \mathrm{~m}^{2},
$$

where $F_{1}, F_{2}, F_{3}$ - the building areas of chambers $1,2,3$.

3.2. Calculation of insulation structure of chamber. The design of the insulating structure of cooled rooms is made taking into account the building structure of fences, thermophysical properties of the layers of the insulating circuit, environmental parameters in different seasons of the year with the involvement of classical calculation methods used in refrigeration [14].

Baseline environmental parameters in Tunisia [7].

Estimated summer air temperature: $t_{s}=35{ }^{\circ} \mathrm{C}$.

Estimated summer humidity of the air: $\varphi_{s}=63 \%$.

Estimated winters air temperature: $t_{w}=7^{\circ} \mathrm{C}$.

Estimated winters humidity of the air: $\varphi_{w}=77 \%$.

Latitude $-36^{\circ} 49^{\prime} 08$.

Actual heat transfer coefficients, all types of protections taking into account use of standard PPU plates [14].

The calculated values of the heat transfer coefficients of the building structure elements of the chambers are presented in Table 2.

Heat transfer coefficient

\begin{tabular}{|l|c|}
\hline \multicolumn{1}{|c|}{ Name of fences } & Heat transfer coefficient, $\mathrm{k} \cdot \mathrm{W} / \mathrm{m}^{2} \cdot \mathrm{K}$ \\
\hline The outer walls are north & 0.245 \\
The outer walls are lateral & 0.368 \\
Attic floors & 0.288 \\
Floor & 0.469 \\
Partitions between the chambers & 0.388 \\
\hline
\end{tabular}

3.3. Calculation of heat inflows in the cooled premises. Calculations of heat inflows into the cooled premises are performed taking into account the insulating structure of external fences, environmental parameters in different seasons, operating conditions and cargo operations in the premises with the involvement of classical calculation methods used in refrigeration [13].

General view of the heat load equation [13]:

$$
Q_{T}=Q_{1}+Q_{2}+Q_{3}+Q_{1}+Q_{5},
$$

where $Q_{T}$ - total load, W; $Q_{1}$ - heat inflows through external protections, W; $Q_{2}$ - heat inflows from cargo during heat treatment, W; $Q_{3}$ - heat flows during ventilation of the chamber, $\mathrm{W} ; Q_{4}-$ heat fluxes from lighting, $\mathrm{W} ; Q_{5}-$ heat from food during respiration, $\mathrm{W} ; Q_{6}-$ heat inflows at opening door, $\mathrm{W} ; Q_{7}-$ heat gain of electric various purpose, W.

The generalized data are presented in Tables 3, 4. As initial parameters six months a year with corresponding values of average temperatures of outdoor air in day and night time of day, conditions of thermal processing of cargoes and their receipt are chosen.

Total values of daily heat flows in the chamber

Table 3

\begin{tabular}{|c|c|c|c|c|c|}
\hline \multicolumn{2}{|c|}{ Day values } & \multicolumn{4}{|c|}{ Chamber } \\
\hline Temperature, ${ }^{\circ} \mathrm{C}$ & Month & $\Sigma \emptyset_{\text {cham } 1, \mathrm{~W}}$ & $\Sigma \emptyset_{\text {cham } 2, ~ W}$ & $\square_{\text {cham } 1}+\square_{\text {cham } 2,}, \mathrm{~W}$ & $\Sigma \emptyset_{\text {cham3 }}, \mathrm{W}$ \\
\hline 35 & July & 30894 & 10963 & 41857 & 6755 \\
\hline 34 & August & 28689 & 10601 & 39290 & 7021 \\
\hline 31 & June & 25467 & 9142 & 34608 & 6299 \\
\hline 26 & October & 19807 & 7375 & 27183 & 5447 \\
\hline 16 & January & 8278 & 3760 & 12038 & 3741 \\
\hline 22 & April & 15139 & 5907 & 21046 & 4694 \\
\hline
\end{tabular}

Chamber

Total values of night heat flows in the chamber

Table 4

\begin{tabular}{c|c}
\hline & Chamber
\end{tabular}

\begin{tabular}{|c|c|c|c|c|c|}
\hline \multicolumn{2}{|c|}{ Night values } & \multicolumn{4}{c|}{ Chamber } \\
\hline Temperature, ${ }^{\circ} \mathrm{C}$ & Month & $\Sigma \emptyset_{\text {cham } 1, \mathrm{~W}}$ & $\Sigma \emptyset_{\text {cham } 2, \mathrm{~W}}$ & $\square_{\text {cham } 1}+\emptyset_{\text {cham } 2, \mathrm{~W}}$ & $\Sigma \emptyset_{\text {cham } 3, \mathrm{~W}}$ \\
\hline 21 & July & 12329 & 4904 & 17233 & 4326 \\
\hline 22 & August & 13338 & 5210 & 18547 & 4614 \\
\hline 18 & June & 8912 & 3836 & 12747 & 3829 \\
\hline 16 & Detober & 6734 & 3162 & 9896 & 3489 \\
\hline 7 & January & 1845 & 1367 & 3212 & 1782 \\
\hline 11 & April & 5460 & 2538 & 7999 & 3226 \\
\hline
\end{tabular}

Note: calculated total of heat gain for determining cooling capacity machines at the same evaporating temperature

3.4. Analysis of thermal load on the camera. The analysis was performed in order to select the design-cycle solution of the refrigeration machine. To analyze the thermal load on refrigeration machine provided in graphical form in Fig. 1, 2.

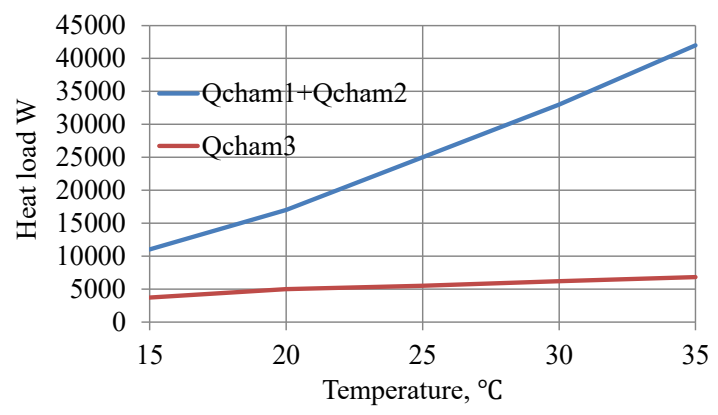

Fig. 1. Heat load in dependence on the daily temperature outside air

The information shows, what the load of high temperature chambers with the temperature of $7{ }^{\circ} \mathrm{C}$ varies widely over the year during the day. The interval of changes makes from 100 to $25 \%$ of the maximum loading. According to these data, the chambers can be cooled by a single-stage refrigerator with medium capacity with control ones.

The heat load on the olive storage chamber has an interval of changes from 100 to $50 \%$ of the maximum load. According to calculations, the chamber can be cooled 
by a small single-stage refrigeration machine with control capacity. In the case of lowering temperature below zero, preventing low freeze citrus product, air in the chamber is heated through ventilation.

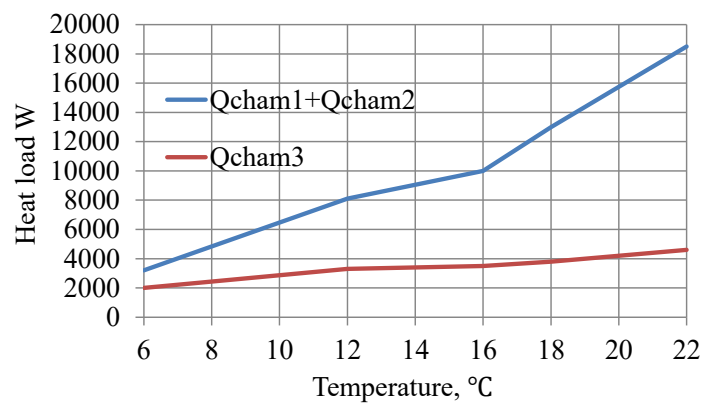

Fig. 2. Figure heat load in dependence on the daily temperature outside air

It is impractical to use two independent refrigerating machines in the conditions of autonomous energy consumption due to large capital costs. Temperature modes allow using the two-stage refrigerating machine with a cycle «Booster system» and $\mathrm{CO}_{2}$ working substance [12].

3.5. Calculation of the refrigeration machine characteristics. Each of the natural refrigerants has its drawbacks and positive qualities. Carbon dioxide is one of the few refrigerants for refrigeration systems, relevant in terms of efficiency and safety for the environment. It can be used in refrigeration systems of various types, both subcritical and transcritical, taking into account the triple and critical points.
The cooling supply of the chambers in the complex is provided by one two-stage refrigeration machine operating at 2 evaporating points with natural working fluid $\mathrm{CO}_{2}$. This system is called «transcritical booster» (Fig. 3).

The use of a booster system is determined by the ratio of heat inflows into chambers with different temperatures. The main heat fluxes fall on chambers with temperatures above zero, and small ones - on the chamber with negative air temperatures. With such a ratio, the upper stage of the HS represents a full-fledged single-stage machine, the lower LS is an additional one, which performs two functions:

1) cooling and freezing a small amount of products;

2) providing energy savings in the entire refrigeration system (transition from single-stage compression with low efficiency to two-stage).

The heat is removed in a gas cooler. An air cooler for a low evaporating point of the HS provides cold storage for the olives. In the storage chambers for citruses s, two air coolers for high evaporating temperature are in operation. The machine is equipped with a regenerative heat exchanger, which provides cooling of the high-pressure gas after the gas cooler and superheating of the medium-pressure vapour before being sucked into the LS compressor. A liquid separator (circulation receiver) provides liquid supply to the air coolers.

The cycle of the machine is shown in Fig. 4 in the diagram $p-h$.

Initial data for the calculation.

Refrigerant: $\mathrm{CO}_{2}$.

Heat load on air coolers in storage chambers 1 and 2 (Tables 3, 4).

Heat load on the air cooler in the chamber 3 (Tables 3, 4).

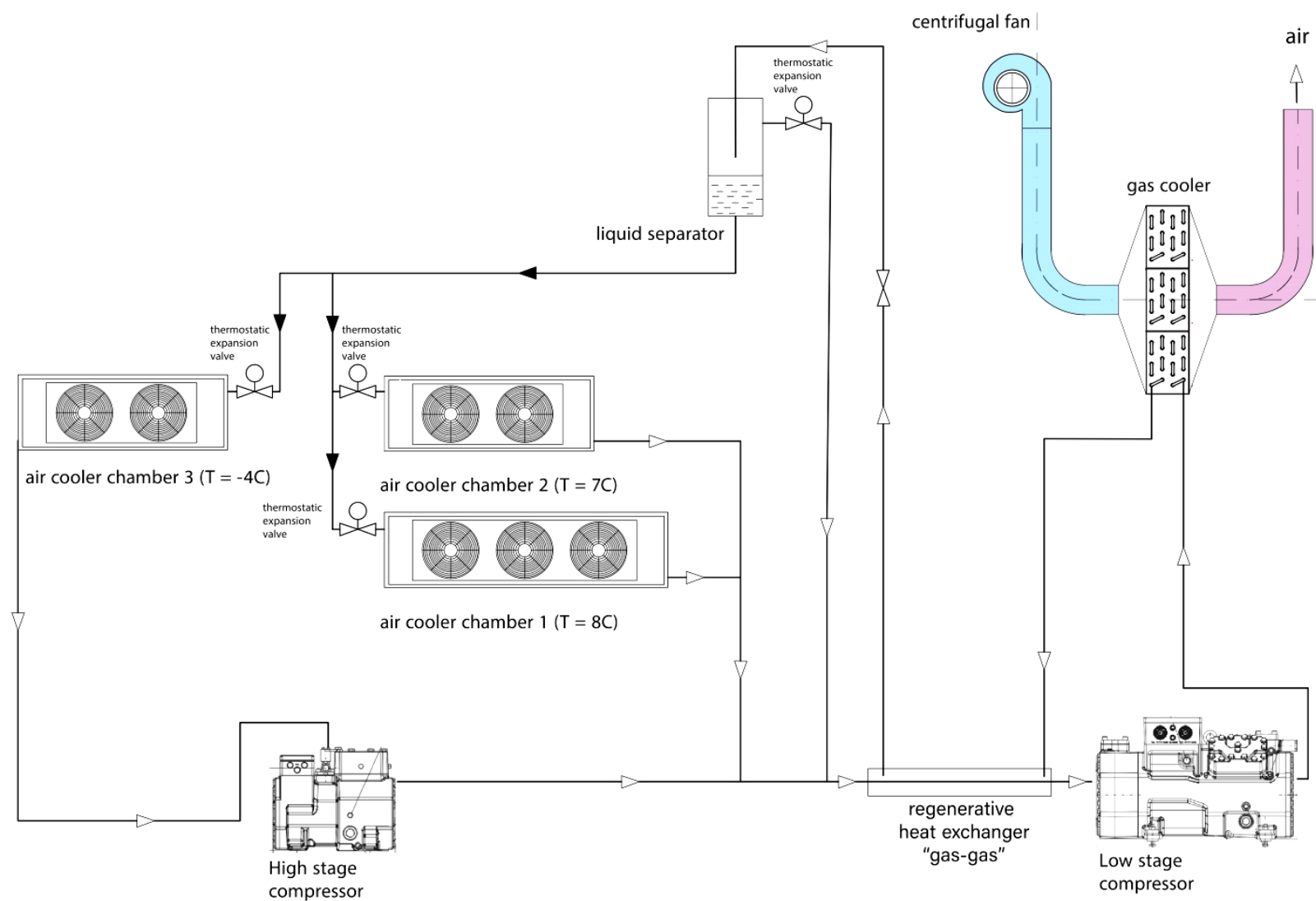

Fig. 3. Technological scheme of the refrigeration machine: 1 - compressor CLS (booster); 2 - heat exchanger; 3 - compressor CHS (main); 4 - gas cooler; 5, 7, 9 - throttle valves; 6 - liquid separator; 8, 10 - air coolers 


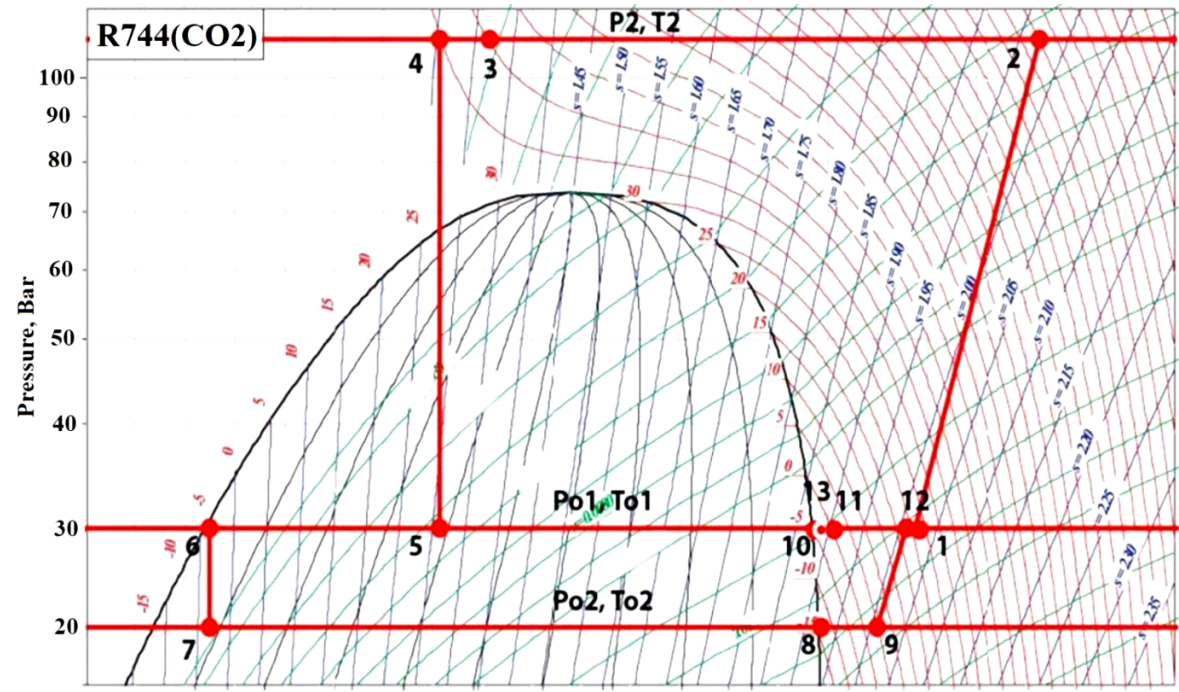

Enthalpy, kJ/kg

Fig. 4. Thermodynamic cycle in diagram $p-h$

High evaporating temperature $t_{01}=-3{ }^{\circ} \mathrm{C}$.

Low evaporating temperature $t_{02}=-14{ }^{\circ} \mathrm{C}$.

The pressure in the gas cooler $p_{2}=11.0 \mathrm{MPa}$.

The temperature at the outlet of the gas cooler $t_{3}=45^{\circ} \mathrm{C}$.

Suction parameters in compressors according $t_{0}$ [5] $t_{1}=25{ }^{\circ} \mathrm{C}, \Delta t_{\text {zs }}=20{ }^{\circ} \mathrm{C}$.

The calculations were performed using classical methods for refrigeration machines of two-stage compression [15]. The results are given in the Table 5 .

Table 5

Summary table of cycle characteristics

\begin{tabular}{|c|c|c|c|c|}
\hline Indicator & \multicolumn{4}{|c|}{ The month of the year } \\
\hline Characteristics & August & October & January & April \\
\hline $4_{01}, \mathrm{KJ} / \mathrm{kg}$ & 243.2 & 243.2 & 243.2 & 243.2 \\
\hline $\mathrm{q}_{02}, \mathrm{KJ} / \mathrm{kg}$ & 239.7 & 239.7 & 239.7 & 239.7 \\
\hline$M_{a 1}, \mathrm{~kg} / \mathrm{s}$ & 0.1668 & 0.1134 & 0.05 & 0.0878 \\
\hline$M_{o 2}, \mathrm{~kg} / \mathrm{s}$ & 0.0271 & 0.0122 & 0.0098 & 0.0113 \\
\hline$M_{\text {gcool }} \mathrm{kg} / \mathrm{s}$ & 0.327 & 0.174 & 0.077 & 0.137 \\
\hline$M_{m \prime} \mathrm{kg} / \mathrm{s}$ & 0.1336 & 0.0484 & 0.0172 & 0.0379 \\
\hline$w_{2}, \mathrm{~kJ} / \mathrm{kg}$ & 14.04 & 14.04 & 14.04 & 14.04 \\
\hline$q_{\text {gcaol }} \mathrm{kJ} / \mathrm{kg}$ & 210.2 & 254.2 & 269.8 & 254.2 \\
\hline$q_{h e l} \mathrm{~kJ} / \mathrm{kg}$ & 37.4 & 24.11 & 22.12 & 24.11 \\
\hline$w_{1}, \mathrm{~kJ} / \mathrm{kg}$ & 66.862 & 66.862 & 66.862 & 66.862 \\
\hline$V_{2}, \mathrm{~m}^{3} / \mathrm{s}$ & 0.0005 & 0.00019 & 0.00015 & 0.00018 \\
\hline$\lambda_{2}$ & 0.953 & 0.953 & 0.953 & 0.953 \\
\hline$V_{h 2}, \mathrm{~m}^{3} / \mathrm{s}$ & 0.00052 & 0.0002 & 0.00015 & 0.00019 \\
\hline$V_{1}, \mathrm{~m}^{3} / \mathrm{s}$ & 0.0047 & 0.0025 & 0.0011 & 0.00196 \\
\hline$\lambda_{1}$ & 0.807 & 0.807 & 0.807 & 0.807 \\
\hline$V_{h 1}, \mathrm{~m}^{3} / \mathrm{s}$ & 0.0057 & 0.00307 & 0.00136 & 0.00243 \\
\hline$N i_{2}, \mathrm{~kW}$ & 0.402 & 0.181 & 0.146 & 0.167 \\
\hline $\mathrm{Ne}_{2}, \mathrm{~kW}$ & 0.433 & 0.193 & 0.155 & 0.178 \\
\hline$N i_{1}, \mathrm{~kW}$ & 25.844 & 13.752 & 6.085 & 10.827 \\
\hline$N e_{1}, \mathrm{~kW}$ & 26.19 & 13.936 & 6.166 & 10.973 \\
\hline$\Phi_{\text {gcool }} \mathrm{kW}$ & 68.75 & 44.23 & 20.777 & 34.825 \\
\hline$\square_{h e r} \mathrm{~kW}$ & 12.23 & 4.195 & 1.70 & 3.30 \\
\hline$\eta_{e e}$ & 0.323 & 0.310 & 0.296 & 0.312 \\
\hline
\end{tabular}

The analysis of the calculation results was carried out in order to select the compressors and the principle of automation of the machine on the basis of energy saving.
Compressors are selected according to the maximum heat inflows into the chambers, which are observed in July, August and June in all chambers of the low-temperature storage system of vegetable raw materials. Theoretical volumetric capacity of compressors is: for the high stage $0.0057 \mathrm{~m}^{3} / \mathrm{s}$, for the lower $-0.00052 \mathrm{~m}^{3} / \mathrm{s}$.

In October, January and April, ambient temperatures drop. Heat flows through the fence of chambers 1 and 2 are reduced, respectively. To ensure energy saving and stable mode in the chambers, it is necessary to reduce the refrigeration capacity of the compressor.

At the same time, the heat load on the chamber 3, respectively on the compressor $\mathrm{LC}$ remains constant, as the heat flows increase during the freezing of olives there is a harvest. All of the above in graphical form is given in Fig. 5-7.

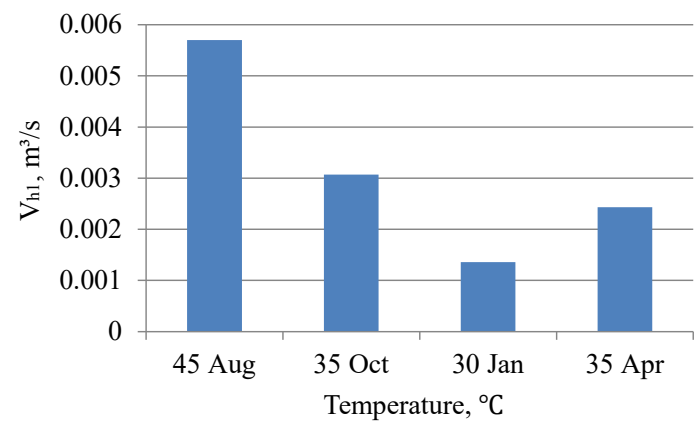

Fig. 5. Dependence $V_{h 1}$ on the ambient temperature

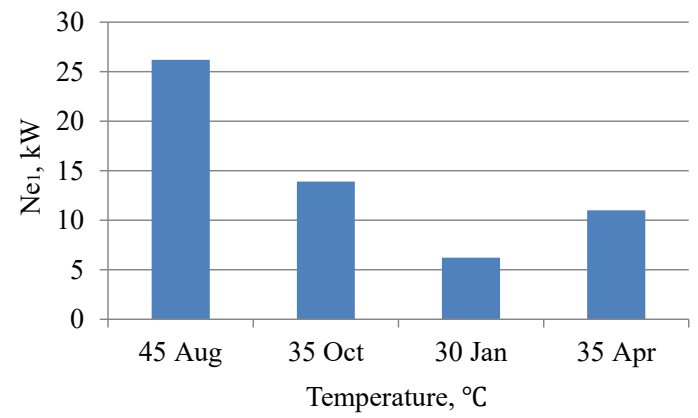

Fig. 6. Dependence of the power $N e_{1}$ on the ambient temperature 
The change in the theoretical volumetric capacity and the power of the high stage compressor is given in graphical form in Fig. 5. 6.

The change of the theoretical volumetric capacity and the power of the lower stage compressor are given in graphical form in Fig. 7. 8.

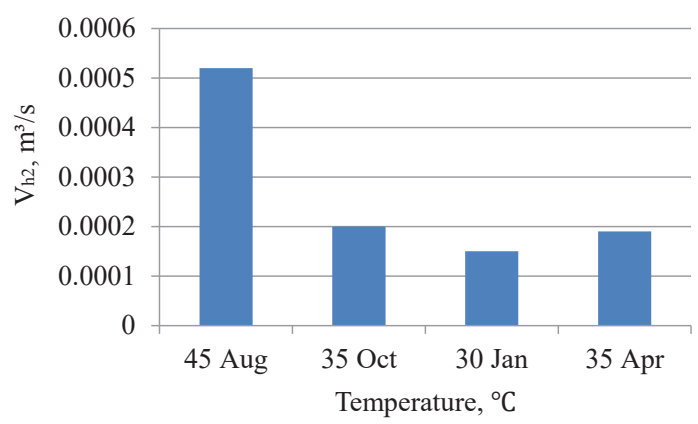

Fig. 7. Dependence $V_{h 2}$ on the ambient temperature

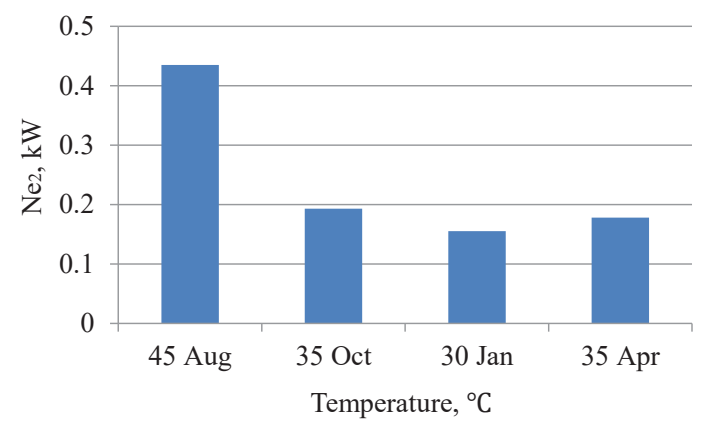

Fig. 8. Dependence of the power $N e_{2}$ on the ambient temperature

The degree of thermodynamic perfection of the machine is $0.29-0.32$ depending on the operating temperature of the machine is given on Fig. 9 .

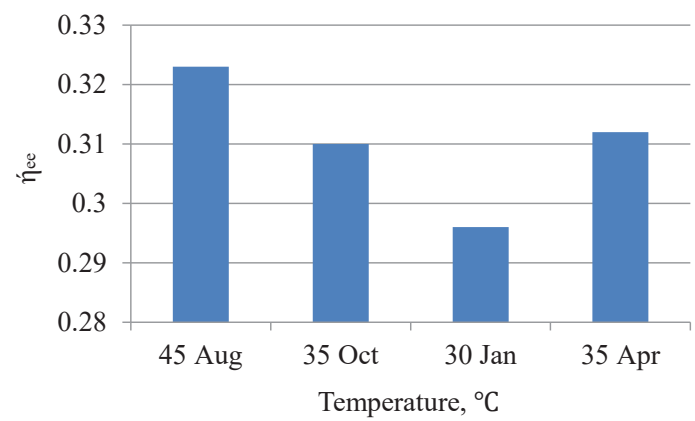

Fig. 9. Dependence of the degree of thermodynamic perfection on the ambient temperature

It can be stated that in the presence of significant fluctuations in ambient temperatures, both seasonal and daily, it is possible to ensure energy savings, thereby removing high energy costs from photovoltaic converters.

3.6. Calculation of the photoelectric converter (PEC). The thermal capacity of an electric solar power plant must meet the needs of a particular consumer during the day at different times of the year [16]. To determine the consumption of electricity requires information on all sources of consumption:

$$
W_{f v}=\sum W_{i} \tau_{i}+N e+W_{f n},
$$

where $W_{f v}$ - electric power of photoelectric converter; $W_{i}$ - power of each electrical appliance in the complex; $\tau_{i}$ - working time during the day, h/day; $N e$ - effective compressor power; $W_{f n}$ - fan power.

The most common modules (made of single-crystal silicon) have a unit power $w_{1}=100-120 \mathrm{~W} / \mathrm{m}^{2}$. So, the area, which is occupied by the converter is:

$$
F_{f v}=\frac{W_{f v}}{w_{1}} .
$$

The calculation of PEC consists of the following main stages: determination of load and energy consumption, determination of the required area of photovoltaic modules.

Below is a simple method of calculating the autonomous PEC for the cooling system of the complex, on the example of data on air temperatures and insolation one day in May (Fig. 10) [17].
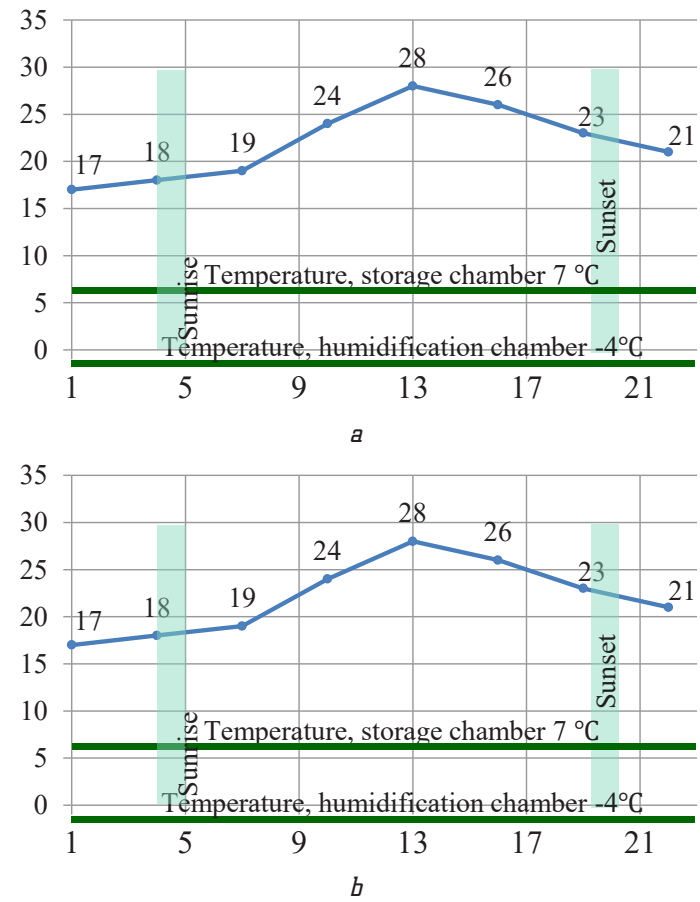

Fig. 10. The period of effective operation of the solar system for May: $a$ - daily daytime temperature; $b$ - daily solar radiation $\mathrm{kW} \cdot \mathrm{h} / \mathrm{m}^{2} \cdot$ day $\cdot 10^{-3}$

The number of electrical appliances (Table 6) is taken based on the average statistics for the office of a small enterprise [17]. The effective power of the compressor and fans is calculated using the data of thermal calculation of the refrigeration machine.

The calculated characteristics of the photovoltaic converter are determined for the complex using the example of the climatic conditions of the month of May and are presented in Table 7 .

The results of calculations of the characteristics of the photovoltaic converter taking into account the degree of natural insolation in Tunisia, seasonal and daily weather conditions in May for the operation of the cooling complex required photovoltaic converter area up to $240 \mathrm{~m}^{2}$ (a unit power $w_{i}=100-120 \mathrm{~W} / \mathrm{m}^{2}$ ). Placement of solar panels is agreed with the consumer [19]. 
Table 6

Electrical household appliances characteristics [18]

\begin{tabular}{|c|c|c|c|c|c|}
\hline Consumer & Power, W & Season & $\begin{array}{c}\text { Average daily } \\
\text { work time, } \\
\text { hours }\end{array}$ & $\begin{array}{c}\text { Daily electric- } \\
\text { ity consump- } \\
\text { tion, } \mathrm{kWh}\end{array}$ \\
\hline \multicolumn{5}{|c|}{ The main regular consumers } \\
\hline Inverter & 20 & always & 24 & 0.48 \\
\hline Lighting, basement & 200 & always & 3 & 0.6 \\
\hline Lighting, 1st floor & 50 & always & 6 & 0.3 \\
\hline Refrigerator & 500 & always & 8 & 4.0 \\
\hline Air conditioning & 500 & always & 5 & 2.5 \\
\hline TV & 300 & always & 2 & 0.6 \\
\hline Computer & 300 & always & 2 & 0.6 \\
\hline Total & - & - & - & 9.1 \\
\hline
\end{tabular}

Estimated characteristics of the photovoltaic converter for May conditions [17]

\begin{tabular}{|l|c|c|}
\hline \multicolumn{1}{|c|}{ Characteristic } & $\begin{array}{c}\text { Units of measure- } \\
\text { ment }\end{array}$ & Value \\
\hline Characteristics of insolation & $\left(\mathrm{kWh} / \mathrm{m}^{2}\right) /$ day & 4 \\
\hline Duration of the mode, storage chambers & $\mathrm{h} / \mathrm{day}$ & 24 \\
\hline Duration of effective operation of PEᄃ & $\mathrm{h} / \mathrm{day}$ & 11 \\
\hline Refrigeration capacity, $\square_{01} / \square_{02}$ & $\mathrm{~kW}$ & $27.2 / 5.5$ \\
\hline Compressor power $N e_{C H S}+N e_{C L S}$ & $\mathrm{~kW}$ & 14.2 \\
\hline Electricity for household needs & $\mathrm{kW}$ & 9.1 \\
\hline Total power of fan motors & $\mathrm{kW}$ & 4.5 \\
\hline Total power of pump motors & $\mathrm{kWh} / \mathrm{d}$ & 0.312 \\
\hline Total electricity consumption & $\mathrm{kWh} / \mathrm{d}$ & 24.11 \\
\hline Estimated power of PEC & $\mathrm{kW} / \mathrm{m}^{2}$ & 0.36 \\
\hline Estimated area of PEC & $\mathrm{m}^{2}$ & 67 \\
\hline
\end{tabular}

In conclusion, we note that the high cost of electricity from PEC constrains their wider use. This high cost is due to the high cost of high purity silicon and process. In the world intensive research and development aimed at reducing the $\mathrm{PEC}$ cost.

\section{Conclusions}

According to the research results, the cooled complex has the following characteristics:

- cargo capacity of cooled chambers;

- thermal load on cooled chambers and thermal capa-

city of the refrigeration system;

- indicators of an autonomous solar power plant (photovoltaic converter).

Cargo capacity depends on the scale of the construction and production facilities of a small private enterprise, the quality and quantity of fruits entering storage.

The heat load during the year on the refrigeration system is determined by the harvest season, the availability and time of heat treatment, the shelf life and climatic conditions of the region where the complex is supposed to be built. Energy saving is achieved by adjusting the characteristics of the refrigeration machine depending on seasonal and daily ambient temperature fluctuations.

The efficiency of the photovoltaic converter is determined by the period of the lowest solar insolation while ensuring the optimal operating modes of the refrigeration system.

A two-stage refrigeration machine with $\mathrm{CO}_{2}$ refrigerant and a transcritical cycle was chosen heuristically, which led to limitations in the study to reduce the search for the optimal variant of the degree of thermodynamic perfection of the machine.

In the future, research can be expanded to include design of compulsory comparative thermodynamic analysis of actual cycles and schemes with different optimal characteristics. These include: the specific refrigerating capacity of the refrigerant, the operating pressure limits in which the cycle operates, the specific volumetric work of compression, environmental indicators that may be of interest to the investor, refusing to search for energy efficiency.

Analysis of the characteristics of a two-stage refrigeration machine with a $\mathrm{CO}_{2}$ refrigerant with two cooling temperatures $\left(-4\right.$ and $\left.7{ }^{\circ} \mathrm{C}\right)$ established that the machine possesses a degree of thermodynamic perfection $\eta_{e e}=0.3$, which is consistent with the terms of energy saving.

The work is a model for the design of an autonomous refrigerated complex, contains all the necessary design elements of production, refrigeration and power supply systems. An investor wishing to implement such a project must have data on the scale of production and energy capabilities of PEC throughout the year.

The project can be implemented in countries and regions with tropical climates.

\section{References}

1. Mirovaya prodovolstvennaya problema. Available at: https:// vuzlit.ru/1211757/mirovaya_prodovolstvennaya_problema

2. Yasin, E. (2010). Prodovolstvennaya programma v mire $i$ v Rossii perspektivy i reshenie. Available at: https://liberal.ru/scientificseminar/bprodovolstvennaya-programma-v-mire-i-v-rossiiperspektivy-i-reshenieb

3. Bashurova, D. (2009). Problemy goloda v mire. Available at: http://diplomba.ru/work/122393

4. Aste, N., Del Pero, C., Leonforte, F. (2017). Active refrigeration technologies for food preservation in humanitarian context A review. Sustainable Energy Technologies and Assessments, 22, 150-160. doi: http://doi.org/10.1016/j.seta.2017.02.014

5. Medved, D. (2011). Trigeneration units. Intensive Programme «Renewable Energy Sources», 47-50. Available at: http://home. zcu.cz/ tesarova/IP/Proceedings/Proc 2011/Files/Medved.pdf

6. Bassols, J., Kuckelkorn, B., Langreck, J., Schneider, R., Veelken, H. (2002). Trigeneration in the food industry. Applied Thermal Engineering, 22 (6), 595-602. doi: http://doi.org/10.1016/ s1359-4311(01)00111-9

7. Energetika Tunisa. Available at: https://knoema.ru/atlas/\%D 0\%A2\%D1\%83\%D0\%BD\%D0\%B8\%D1\%81/topics/\%D0\%AD $\%$ D0\%BD\%D0\%B5\%D1\%80\%D0\%B3\%D0\%B5\%D1\%82\%D0 $\% \mathrm{~B} 8 \% \mathrm{D} 0 \% \mathrm{BA} \% \mathrm{D} 0 \% \mathrm{~B} 0$

8. Tassou, S. A., Lewis, J. S., Ge, Y. T., Hadawey, A., Chaer, I. (2010). A review of emerging technologies for food refrigeration applications. Applied Thermal Engineering, 30 (4), 263-276. doi: http://doi.org/10.1016/j.applthermaleng.2009.09.001

9. Tunis - strana - proizvoditel tropicheskoy selkhozproduktsii. Available at: https://ru.wikipedia.org/wiki/Тунис

10. Sezony fruktov v Tunise. Available at: https://summerhotels. $\mathrm{ru} /$ tunisia/stati-o-tunise/sezony-fruktov-v-tunise/

11. Metody khraneniya olivok (2017). Available at: https://oliva. $\mathrm{su} / \mathrm{blog} /$ perspektivnye-metody-hraneniya-olivok

12. Kim, Y. M., Kim, C. G., Favrat, D. (2012). Transcritical or supercritical CO2 cycles using both low- and high-temperature heat sources. Energy, 43 (1), 402-415. doi: http://doi.org/ 10.1016/j.energy.2012.03.076 
13. Yavnel, B. K. (1989). Kursovoe i diplomnoe proektirovanie kholodilnykh ustanovok i sistem konditsionirovaniya vozdukha. Moscow: Agropromizdat, 233

14. Chumak, I. G. et. al. (1981). Kholodilnye ustanovki. Moscow: Legkaya i pischevaya promyshlennost, 344.

15. Morozyuk, T. V. (2006). Teoriya kholodilnykh mashin i teplovykh nasosov. Odessa: Studiva «Negotsiant», 712.

16. Solnechnaya energiya. Available at: https://akbinfo.ru/alternativa/solnechnaja-jenergija.html

17. Raschet solnechnoy elektrostantsii. Available at: https:// avtonomny-dom.ru/solnechnyie-batarei/raschet-solnechnoyelektrostantsii.html

18. Kilkist elektropryladiv seredni statystychni dani (2018). Available at: https://eenergy.com.ua/korysni-porady/rozrahunokspozhyvannya-elektroenergiyi/

19. Soniachni paneli. Internet-mahazyn soniachnykh panelei. Available at: https://teplota.ua/shop/solnechnaya-batareya-jinkosolar-310-vt-24-v,-polikristallicheskaya-jkm310p-304494p.html

Larisa Morozyuk, Doctor of Technical Sciences, Professor, Department of Cryogenic Technique, Odessa National Academy of Food
Technologies, Odessa, Ukraine, ORCID: https://orcid.org/0000-00034133-1984, e-mail: lara.morozyuk@mail.ru

Viktoriia Sokolovska-Yefymenko, PhD, Associate Professor, Department of Cryogenic Technique, Odessa National Academy of Food Technologies, Odessa, Ukraine, ORCID: https://orcid.org/00000002-7275-5061, e-mail: kli24062006@gmail.com

Yaroslav Petushkov, Department of Cryogenic Technique, Odessa National Academy of Food Technologies, Odessa, Ukraine, ORCID: https:// orcid.org/0000-0002-4001-2001,e-mail: garbageskott@gmail.com

Maksym Sharaiev, Department of Cryogenic Technique, Odessa National Academy of Food Technologies, Odessa, Ukraine, ORCID: https:// orcid.org/0000-0002-2903-7195,e-mail: maksymsharaev@gmail.com

Sergii Psarov, Postgraduate Student, Department of cryogenic technique, Odessa National Academy of Food Technologies, Odessa, Ukraine, e-mail: psaryov1979@gmail.com 